\title{
Pengaruh Kenaikan Harga Rokok terhadap Perilaku Merokok pada Kelompok Usia Remaja: Literature Review
}

\author{
Zuhria Wahidah Nurhidayah, Rara Warih Gayatri*, Suci Puspita Ratih \\ Universitas Negeri Malang, Jl. Semarang No. 5 Malang, Jawa Timur, Indonesia \\ *Penulis korespondensi, Surel: rara.warih.fik@um.ac.id
}

Paper received: 2-12-2021; revised: 20-12-2021; accepted: 28-12-2021

\begin{abstract}
Cigarettes are one of the factors of world health issues that have not been resolved until now. The number of smokers in the world in 2015 reached 1.3 billion people, while Indonesia being the first billion smokers in ASEAN with 65 million smokers and 69 percent dominated by teenagers. The World Health Organization (WHO) has determined the reduction of cigarette consumption as one of the Global NCDs Targets to be achieved by 2025 by increasing the action of increasing the tax price of all cigarette products to reduce the demand for cigarettes. Indonesia applies the same thing by issuing the Peraturan Menteri Keuangan Republik Indonesia no. 198 Tahun 2020 concerning the policy on the price of cigarettes smoking 12.5 percent in order to reduce the prevalence of smoking in the 10-18 year age range from 9.1 percent to 5.4 percent in 2029 according to the RPJMN. The purpose of this study is to analyze research studies that have been conducted to describe the effect of rising cigarette prices on adolescent smoking behavior. The data used in this literature study are articles that are relevant to the inclusion and exclusion criteria that have been determined within a span of 10 years that have been published in selected databases, which are Proquest, Pubmed, and Google Scholar. Stages of selection using the PRISMA flow chart. Assessment of article quality used the Strengthening The Reporting of Observational Studies in Epidemiology (STROBE) checklist. The results of this literature study contained 7 (seven) articles that were analyzed. These articles describe the effect of increasing cigarette prices on decreasing smoking initiation, smoking consumption, and smoking prevalence.
\end{abstract}

Keywords: increase in cigarette prices; smoking behavior; adolescent

\begin{abstract}
Abstrak
Rokok merupakan salah satu faktor masalah kesehatan dunia yang belum terselesaikan sampai saat ini. Jumlah perokok di dunia pada tahun 2015 diestimasikan mencapai 1,3 milyar orang di mana Indonesia menempati peringkat pertama perokok terbesar di ASEAN dengan jumlah 65 juta perokok dan 69 persen didominasi remaja. World Health Organization (WHO) menetapkan pengurangan konsumsi rokok sebagai salah satu Global NCDs Target yang akan dicapai pada tahun 2025 dengan prioritas aksi peningkatan harga pajak semua produk rokok untuk mengurangi permintaan rokok. Indonesia menerapkan hal serupa yaitu dengan mengeluarkan Peraturan Menteri Keuangan Republik Indonesia nomor 198 Tahun 2020 mengenai kebijakan harga rokok yang dinaikkan 12,5 persen guna menekan prevalensi merokok remaja rentang usia 10 - 18 tahun dari angka 9,1 persen menjadi 5,4 persen di tahun 2029 sesuai dengan RPJMN. Tujuan dari penelitian ini yaitu untuk menganalisis studi-studi penelitian yang telah dilakukan untuk menggambarkan pengaruh dari kenaikan harga rokok terhadap perilaku merokok remaja. Data yang digunakan dalam studi literatur ini merupakan artikel-artikel yang relevan dengan kriteria inklusi dan eksklusi yang telah ditentukan dengan rentang 10 tahun yang telah terpublikasi pada database pilihan yaitu Proquest, Pubmed, dan Google Scholar. Tahapan seleksi menggunakan PRISMA flow diagram. Penilaian kualitas artikel menggunakan Strengthening The Reporting of Observational Studies in Epidemiology (STROBE) checklist. Hasil pada studi literatur ini terdapat 7 (tujuh) artikel yang dianalisis. Artikel-artikel tersebut menggambarkan adanya pengaruh kenaikan harga rokok terhadap penurunan inisiasi merokok, konsumsi merokok, dan prevalensi merokok.
\end{abstract}

Kata kunci: kenaikan harga rokok; perilaku merokok; remaja 


\section{Pendahuluan}

Rokok merupakan salah satu faktor masalah kesehatan dunia yang sampai saat ini masih marak ditemui. Jumlah perokok di dunia pada tahun 2015 diestimasikan mencapai 1,3 milyar orang (Tobacco Control Support Centre-IAKMI, 2015). Indonesia sendiri menempati peringkat pertama dengan jumlah perokok terbanyak di negara ASEAN yaitu mencapai 65 juta perokok yang didominasi oleh kelompok usia remaja dan terus meningkat setiap tahunnya (SEATCA, 2021). Terdapat sekitar 69\% remaja merupakan perokok aktif yang mayoritas dilatarbelakangi oleh keluarga yang perokok (TCSC IAKMI, 2013). Global Youth Tobacco Survey yang dilakukan oleh WHO (2018) mencatat sebanyak 35,3\% remaja dalam kelompok umur 13-15 tahun di Indonesia merupakan perokok. Berdasarkan data yang dikutip dari Riset Kesehatan Dasar (Riskesdas) (Kementerian Kesehatan RI, 2018) proporsi remaja pada kelompok umur 15-19 tahun yang merokok sebesar 19,6\%. Inisiasi merokok (WHO, 2018) di Indonesia juga dimulai pada kelompok umur tersebut tepatnya pada usia 17,6 tahun. Oleh karena itu, Indonesia mendapat julukan baby smoker country.

Organisasi Kesehatan Dunia, World Health Organization (WHO) menetapkan pengurangan konsumsi rokok sebagai salah satu Global Non-Communicable Diseases (NCDs) Target yang akan dicapai pada tahun 2025 (World Health Organization, 2016) dengan prioritas aksi yang salah satunya tertuang pada pasal 6 dalam WHO Framework Convention of Tobacco Control (WHO FCTC) yaitu peningkatan harga pajak semua produk rokok untuk mengurangi permintaan masyarakat terhadap rokok (World Health Organization, 2003). Kebijakan harga dan pajak cukai rokok juga merupakan salah satu kebijakan yang diimplementasikan untuk mereduksi jumlah perokok selain kebijakan lain yang sudah diterapkan seperti pemasangan gambar peringatan kesehatan pada setiap kemasan rokok yang terbukti lebih efektif dalam upaya pencegahan inisiasi merokok pada anak serta upaya berhenti merokok dibandingkan dengan peringatan yang hanya berupa teks (Ratih \& Susanna, 2018). Kebijakan mengenai cukai rokok diatur dalam Peraturan Menteri Keuangan Republik Indonesia nomor 198 Tahun 2020 yang menyebutkan harga rokok dinaikan $12,5 \%$ dari yang sebelumnya stagnan pada $10 \%$.

Di lain sisi, kebijakan harga dan pajak rokok di Indonesia nyatanya masih lambat dibandingkan negara lain. Cukai yang diterapkan di Indonesia yaitu sekitar 49\% dari Harga Jual Eceran (HJE) masih jauh dari tolok ukur yang ditetapkan WHO yaitu 70\% dari HJE (Cahn et al., 2013). Hal ini membuat harga rokok murah dan menyebabkan Indonesia tertinggal dalam penerimaan cukai yang lebih besar dibandingkan negara ASEAN lainnya. Mengingat adanya target pemerintah dalam RPJMN untuk menurunkan prevalensi perokok anak rentang usia 10 - 18 tahun dari angka 9,1\% menjadi 8,7\% di tahun 2024 dan 5,4\% di tahun 2029 (Kementerian Kesehatan RI, 2020), kenaikan harga rokok di Indonesia masih dinilai kurang dan belum mampu untuk mewujudkan target yang ingin dicapainya. Dibandingkan dengan negara ASEAN lainnya seperti Brunei, Myanmar, Malaysia, dan Singapura, harga rokok di Indonesia masih tergolong murah yaitu sekitar 1,6-1,9 USD (SEATCA, 2019, 2021). Penelitian ini bertujuan untuk menganalisis studi-studi penelitian yang telah dilakukan untuk menggambarkan pengaruh dari kenaikan harga rokok terhadap perilaku merokok remaja. Dengan adanya penelitian ini, maka Pemerintah Indonesia bisa lebih menilai besaran dampak dari kenaikan harga rokok sehingga mempertimbangkan mengenai penerapan kenaikan harga yang jauh lebih tinggi. Harga rokok yang tinggi memberikan prediksi rokok tidak dapat terjangkau oleh para perokok di bawah umur (Dartanto, et al., 2020). 


\section{Metode}

\subsection{Sumber Data}

Penelitian ini merupakan studi literatur yang menggunakan data sekunder yang didapat dari artikel-artikel yang relevan dengan topik bahasan dan terpublikasi dalam rentang waktu 10 tahun terakhir. Artikel-artikel tersebut didapatkan dari database yang sudah ditentukan sebelumnya. Database yang akan digunakan dalam penelitian ini adalah ProQuest, Pubmed, dan Google Scholar. Literature Review ini dilakukan mulai Januari 2021 sampai dengan Mei 2021.

Dalam penelitian ini, search term yang digunakan untuk pencarian artikel pada database adalah "Cigarette's Price or Tobacco Excise Rates and Smoking Behavior or Tobacco Consumption and Adolescent or Youth". Search term tersebut digunakan pada database ProQuest dan Pubmed, sedangkan search term yang digunakan pada Google Scholar yaitu "Kenaikan Harga Rokok or Tarif Cukai Rokok and Perilaku Merokok or Konsumsi Rokok and Remaja”. Dalam penyeleksian artikel, ditentukan kriteria inklusi dan eksklusi dengan PICOS Framework (Tabel 1). Sedangkan penilaian kualitas artikel menggunakan Strengthening The Reporting of Observational Studies in Epidemiology (STROBE) checklist yang sudah diterjemahkan kedalam bahasa Indonesia.

\subsection{Ekstraksi data}

Dari hasil pencarian dengan kata kunci yang dikombinasikan dengan Boolean operator didapatkan sebanyak 1.613 artikel dengan rincian 294 artikel dari ProQuest, 486 artikel dari Pubmed, dan 833 artikel dari Google Scholar. Setelah mengeluarkan artikel yang terindikasi duplikasi, artikel kemudian diseleksi berdasarkan judul yang kemudian dikeluarkan sebanyak 771 artikel. Selanjutnya 155 artikel dikeluarkan setelah meninjau desain studi, metode, variabel, dan tujuan penelitian. Artikel yang tersisa kemudian dinilai kualitasnya untuk memperoleh hasil final artikel yang nantinya akan dianalisis. Strategi dan tahapan dalam ekstraksi data dapat digambarkan dalam diagram alir PRISMA (Gambar 1).

\section{Hasil dan Pembahasan}

Sebanyak 7 (tujuh) artikel telah memenuhi kriteria inklusi yang ditentukan serta lolos uji kualitas dengan nilai kualitas baik dengan rincian 6 artikel merupakan artikel Internasional dan 1 artikel merupakan artikel Nasional. Kualitas artikel dinilai dengan STROBE checklist yang mengeluarkan satu artikel dikarenakan hanya berhasil memenuhi $45 \%$ kriteria yang ditentukan.

\subsection{Desain dan Analisis Statistik}

Artikel yang sudah melalui finalisasi kemudian dibedah secara rinci hingga mendapatkan informasi yang dibutuhkan seperti desain dan analisis statistik yang digunakan dalam studi tersebut (Tabel 2). Analisis yang digunakan pada setiap artikel menggunakan analisis regresi. Namun, terdapat pula kriteria-kriteria yang tidak dicantumkan pada beberapa artikel seperti periode, metode pengumpulan data, dan metode pemilihan responden. 
Tabel 1. Karakteristik Responden

\begin{tabular}{|c|c|c|}
\hline Kriteria & Inklusi & Eksklusi \\
\hline Population & $\begin{array}{l}\text { Remaja atau pemuda usia } 10- \\
24 \text { tahun yang merupakan } \\
\text { perokok pemula atau perokok } \\
\text { aktif }\end{array}$ & $\begin{array}{l}\text { Remaja perokok dengan kategori } \\
\text { usia yang tidak terkonfirmasi dengan } \\
\text { baik }\end{array}$ \\
\hline Intervention & $\begin{array}{l}\text { Ada intervensi harga sebagai } \\
\text { kebijakan pengendalian } \\
\text { tembakau }\end{array}$ & $\begin{array}{l}\text { Intervensi kebijakan pengendalian } \\
\text { tembakau lain selain harga seperti } \\
\text { larangan iklan, kawasan tanpa rokok, } \\
\text { dan lain sebagainya. }\end{array}$ \\
\hline Comparison & - & - \\
\hline Outcomes & $\begin{array}{l}\text { Menggambarkan pengaruh } \\
\text { kenaikan harga rokok dengan } \\
\text { perilaku merokok }\end{array}$ & $\begin{array}{l}\text { Menggambarkan pengaruh kenaikan } \\
\text { harga rokok selain inisiasi merokok, } \\
\text { konsumsi rokok, dan prevalensi } \\
\text { merokok }\end{array}$ \\
\hline Study Design & $\begin{array}{l}\text { Artikel yang menggunakan } \\
\text { desain studi korelatif Cross- } \\
\text { sectional }\end{array}$ & $\begin{array}{l}\text { Artikel yang menggunakan desain } \\
\text { studi korelatif lain seperti Cohort, } \\
\text { Case Control, dan lain sebagainya }\end{array}$ \\
\hline Publication type & $\begin{array}{l}\text { Artikel yang dipublikasikan } \\
\text { baik di jurnal Internasional } \\
\text { maupun Nasional dengan } \\
\text { topik bahasan yang sesuai } \\
\text { topik yang akan diteliti }\end{array}$ & $\begin{array}{l}\text { Artikel yang bukan merupakan hasil } \\
\text { penelitian seperti hasil publikasi } \\
\text { dalam conference atau proceeding }\end{array}$ \\
\hline Publication years & $2011-2020$ & Tahun publikasi tidak terdefinisi \\
\hline Language & Indonesia dan/ atau Inggris & $\begin{array}{l}\text { Artikel dengan bahasa selain Inggris } \\
\text { dan Indonesia }\end{array}$ \\
\hline Additional & $\begin{array}{l}\text { Artikel yang dapat diakses full } \\
\text { paper }\end{array}$ & $\begin{array}{l}\text { Artikel yang memerlukan izin akses } \\
\text { atau yang tidak dapat diunduh full } \\
\text { paper }\end{array}$ \\
\hline
\end{tabular}

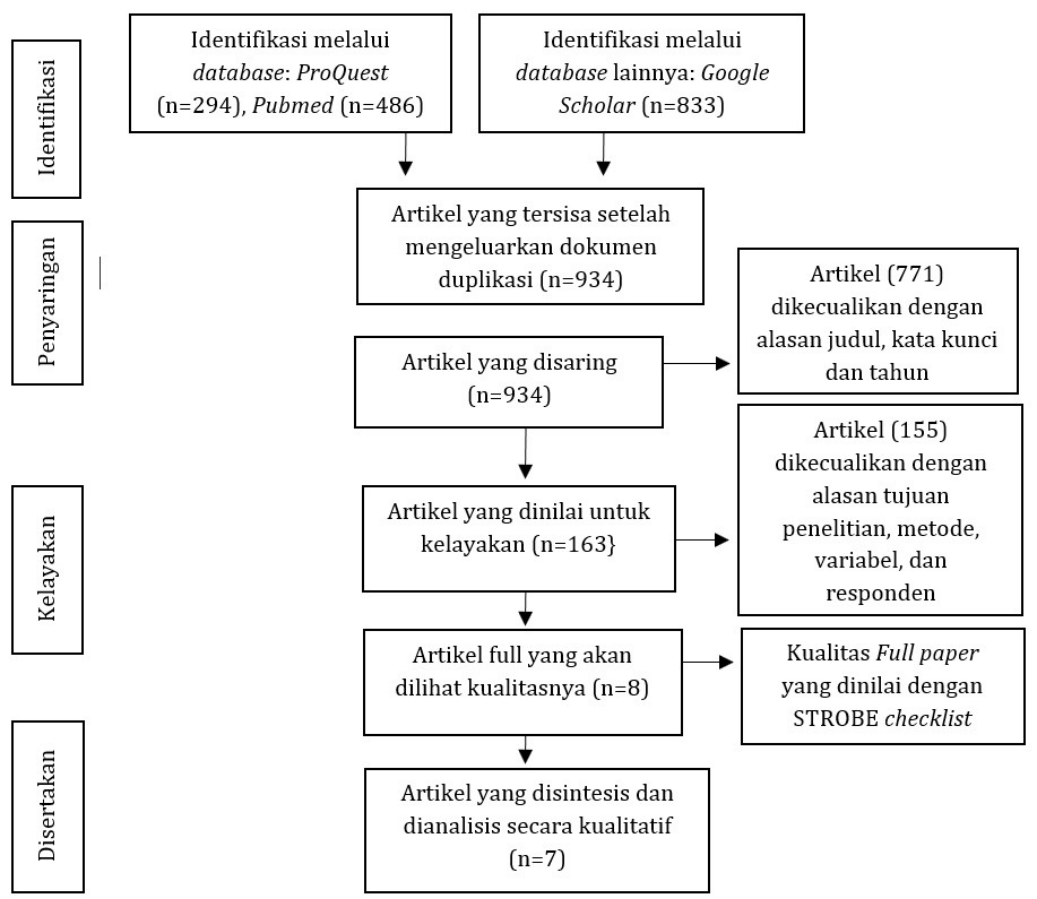

Gambar 1. PRISMA Flow Diagram Literature Review Pengaruh Kenaikan Harga Rokok terhadap Perilaku Merokok pada Kelompok Usia Remaja 


\subsection{Karakteristik Studi}

Pada Tabel 3, terdapat kemiripan karakteristik demografi yang dimiliki responden pada setiap artikel. Pada artikel Guindon et al, Cui et al, Joseph \& Chaloupka, Pförtner et al, dan Nikaj \& Chaloupka jenis kelamin subjek yang akan menjadi responden dalam penelitiannya adalah laki-laki maupun perempuan. Responden pada studi memiliki rentang usia yang sesuai dengan rentang usia remaja yang telah ditentukan dalam kriteria penelitian ini yaitu 10-24 tahun.

\subsection{Hasil Analisis Studi}

Pada bagian ini, analisis yang telah dilakukan terhadap setiap artikel hasil pencarian studi literatur kemudian diklasifikasikan berdasarkan kelompok-kelompok tertentu hingga menghasilkan informasi yang jelas Berikut ringkasan dari hasil analisis studi yang ditampilkan dalam Tabel 4. Umumnya, perubahan perilaku merokok responden yang disebabkan oleh intervensi harga pada setiap artikel terbagi menjadi 3 kategori yaitu perubahan terhadap inisiasi merokok, perubahan terhadap pola konsumsi rokok, dan perubahan pada prevalensi merokok. Sedangkan kategori sensitivitas merupakan informasi tambahan pada artikel yang menunjukkan sensitivitas pada kelompok tertentu dibandingkan dengan kelompok lainnya. Penilaian sensitivitas ini dapat terjadi menurut jenis kelamin yaitu antara laki-laki dan perempuan maupun menurut kondisi sosial ekonomi bahkan tingkat pendidikan. Hubungan mengenai pengaruh intervensi pada harga terhadap perilaku merokok responden akan diuraikan sebagai berikut:

\subsubsection{Pengaruh Kenaikan Harga terhadap Inisiasi Merokok}

Inisiasi merokok diartikan sebagai sebuah proses mencoba rokok hingga menjadi perokok berat yang pada mulanya tidak pernah merokok (Mayhew, Flay, \& Mott, 2000). Artikel yang memiliki korelasi antara kenaikan harga dan inisiasi merokok yaitu artikel Asare, et al., Guindon et al, Cui et al, dan Joseph \& Chaloupka. Pada inisiasi merokok, koefisien elastisitas rata-rata memiliki nilai lebih dari 1 . Hal ini menunjukkan dengan perubahan harga sebesar $1 \%$ mampu menurunkan lebih dari 1\% inisiasi merokok secara absolut. Maknanya, perubahan harga kecil dapat memberi pengaruh yang besar terhadap penurunan inisiasi merokok remaja. Penelitian Gonzalez-Rozada \& Montamat (2019) mengungkapkan bahwa kenaikan harga rokok akan lebih memberikan pengaruh pada pencegahan merokok daripada menghentikan perilaku merokok.

Harga berkaitan dengan keterjangkauan/ affordability yang mana apabila harga rokok semakin tinggi maka rokok menjadi tidak terjangkau bagi remaja (Fransiska \& Firdaus, 2019; Rachmat, Thaha, \& Syafar, 2013). Ditambah lagi remaja merupakan kelompok umur yang ratarata belum memiliki pendapatan pribadi. Sumber pendapatan utama dan satu-satunya adalah uang saku dari orang tua. Uang saku dan harga rokok inilah yang menjadi faktor keterjangkauan yang dapat mempengaruhi remaja merokok (Destri, Sari, \& Perdana, 2019). Selain itu, penelitian tersebut juga menambahkan bahwa dengan kenaikan $10 \%$ harga rokok akan membuat remaja menunda onset merokok selama 2 tahun. Pernyatan tersebut didukung pula oleh hasil studi dari Glied (2002) dalam Sugiharti et al (2015) yang melaporkan bahwa kenaikan harga rokok mampu menunda waktu mulai merokok pada remaja. Selain itu, kelompok usia yang responsif terhadap perubahan harga rokok dibandingkan dengan kelompok lainnya (Brathwaite, Addo, Smeeth, \& Lock, 2015). 
Tabel 2. Identifikasi Artikel

\begin{tabular}{|c|c|c|c|c|c|}
\hline $\begin{array}{l}\text { Penulis dan } \\
\text { Tahun }\end{array}$ & Judul Jurnal & $\begin{array}{c}\text { Negara } \\
\text { Penelitian }\end{array}$ & Jurnal & Indeks & Publisher \\
\hline $\begin{array}{l}\text { Asare et al. } \\
(2019)\end{array}$ & $\begin{array}{l}\text { Effects of Prices on Youth Cigarette Smoking and } \\
\text { Tobacco Use Initiation in Ghana and Nigeria }\end{array}$ & $\begin{array}{l}\text { Ghana dan } \\
\text { Nigeria }\end{array}$ & $\begin{array}{l}\text { International Journal of } \\
\text { Environmental Research and Public } \\
\text { Health }\end{array}$ & Q2- Scopus & MDPI \\
\hline $\begin{array}{l}\text { Guindon et al. } \\
\text { (2019) }\end{array}$ & $\begin{array}{l}\text { Association of Tobacco Control Policies with Youth } \\
\text { Smoking Onset in Chile }\end{array}$ & Chile & JAMA Pediatrics & Q1- Scopus & NCBI \\
\hline Cui et al. (2018) & $\begin{array}{l}\text { The Effects of Cigarette Price and The Amount of } \\
\text { Pocket Money on Youth Smoking Initiation and } \\
\text { Intensity in Canada }\end{array}$ & Canada & Canadian Journal of Public Health & Q2- Scopus & Springerlink \\
\hline $\begin{array}{l}\text { Joseph \& } \\
\text { Chaloupka } \\
(2014)\end{array}$ & $\begin{array}{l}\text { The Influence of Prices on Youth Tobacco Use in } \\
\text { India }\end{array}$ & India & Nicotine and Tobacco Research & Q1- Scopus & $\begin{array}{l}\text { Oxford } \\
\text { Journals }\end{array}$ \\
\hline $\begin{array}{l}\text { Pförtner et al. } \\
(2016)\end{array}$ & $\begin{array}{l}\text { Socioeconomic Inequalities in The Impact of } \\
\text { Tobacco Control Policies on Adolescent Smoking. A } \\
\text { Multilevel Study in } 29 \text { European Countries }\end{array}$ & Europe & Addictive Behaviors Reports & Q1- Scopus & Science Direct \\
\hline $\begin{array}{l}\text { Nikaj \& } \\
\text { Chaloupka } \\
(2014)\end{array}$ & $\begin{array}{l}\text { The Effect of Prices on Cigarette Use Among } \\
\text { Youths in The Global Youth Tobacco Survey }\end{array}$ & Global & Nicotine and Tobacco Research & Q1- Scopus & $\begin{array}{l}\text { Oxford } \\
\text { Journals }\end{array}$ \\
\hline $\begin{array}{l}\text { Sagitha dkk } \\
\text { (2019) }\end{array}$ & $\begin{array}{l}\text { Pengaruh Kenaikan Harga Rokok, Pendapatan, } \\
\text { dan Karakteristik Perokok terhadap Konsumsi } \\
\text { Rokok di Kota Semarang }\end{array}$ & Indonesia & Diponegoro Journal of Economics & GARUDA & $\begin{array}{l}\text { Fakultas } \\
\text { Ekonomika } \\
\text { dan Bisnis } \\
\text { Universitas } \\
\text { Diponegoro } \\
\end{array}$ \\
\hline
\end{tabular}


Tabel 3. Desain dan Analisis Statistik Hasil Pencarian Studi Literatur

\begin{tabular}{|c|c|c|c|c|c|c|c|}
\hline Penulis & Negara & Periode & Desain & $\begin{array}{c}\text { Metode } \\
\text { Pengumpulan } \\
\text { Data }\end{array}$ & $\begin{array}{l}\text { Pemilihan } \\
\text { Responden }\end{array}$ & Responden & Analisis Statistik \\
\hline Asare et al. & $\begin{array}{l}\text { Ghana dan } \\
\text { Nigeria }\end{array}$ & $\begin{array}{l}\text { GYTS } \\
\text { Ghana: wave 1-3 } \\
\text { 2000, 2006, 2009) } \\
\text { Nigeria: } \\
\text { wave } 1 \text { dan } 2 \text { (2000 dan } \\
\text { 2008) }\end{array}$ & $\begin{array}{l}\text { Cross- } \\
\text { sectional, } \\
\text { Survey }\end{array}$ & - & $\begin{array}{l}\text { Metode two } \\
\text { stage cluster } \\
\text { sample }\end{array}$ & $\begin{array}{l}\text { Siswa berusia 11- } \\
18 \text { tahun }\end{array}$ & $\begin{array}{l}\text { Regresi Logistik } \\
\text { Nominal Model } \\
\text { Logit }\end{array}$ \\
\hline $\begin{array}{l}\text { Guindon et } \\
\text { al. }\end{array}$ & Chile & $\begin{array}{l}\text { GYTS } 8 \text { waves Oktober - } \\
\text { Desember }(2001,2003, \\
2005,2007,2009,2011, \\
2013,2015)\end{array}$ & $\begin{array}{l}\text { Cross- } \\
\text { sectional } \\
\text { Survey }\end{array}$ & Wawancara & - & $\begin{array}{l}\text { Siswa, 16-19 } \\
\text { tahun }\end{array}$ & $\begin{array}{l}\text { Regresi Logistik } \\
\text { Nominal }\end{array}$ \\
\hline Cui et al. & Canada & $\begin{array}{l}\text { Canadian Youth Smoking } \\
\text { Survey } 2012 \text { dan } 2013\end{array}$ & $\begin{array}{l}\text { Cross- } \\
\text { sectional } \\
\text { Survey } \\
\end{array}$ & Kuesioner & - & $\begin{array}{l}\text { Siswa kelas 7-12 } \\
\text { (SMP dan SMA) }\end{array}$ & $\begin{array}{l}\text { Regresi Logistik } \\
\text { Berganda dan } \\
\text { Regresi Linier } \\
\end{array}$ \\
\hline $\begin{array}{l}\text { Joseph \& } \\
\text { Chaloupka }\end{array}$ & India & GYTS 1999-2004 & $\begin{array}{l}\text { Cross- } \\
\text { sectional } \\
\text { Survey } \\
\end{array}$ & Kuesioner & - & Siswa kelas 8-10 & $\begin{array}{l}\text { Regresi Model } \\
\text { Probit }\end{array}$ \\
\hline Pförtner et al. & Europe & HBSC 29 negara & $\begin{array}{l}\text { Cross- } \\
\text { sectional }\end{array}$ & Kuesioner & $\begin{array}{l}\text { Metode } \\
\text { clustered } \\
\text { sample } \\
\end{array}$ & $\begin{array}{l}\text { Siswa Usia } 11,13 \text {, } \\
\text { dan } 15 \text { tahun }\end{array}$ & $\begin{array}{l}\text { Regresi Logistik } \\
\text { Berganda }\end{array}$ \\
\hline $\begin{array}{l}\text { Nikaj \& } \\
\text { Chaloupka }\end{array}$ & Global & $\begin{array}{l}\text { GYTS } 38 \text { negara } 3 \text { waves } \\
\text { tahun } 1999-2008\end{array}$ & $\begin{array}{l}\text { Cross- } \\
\text { sectional }\end{array}$ & - & - & $\begin{array}{l}\text { Remaja berusia } \\
\text { 11-19 tahun }\end{array}$ & $\begin{array}{l}\text { Regresi Linier, } \\
\text { Model Logit }\end{array}$ \\
\hline Sagitha et al & Indonesia & - & $\begin{array}{l}\text { Cross- } \\
\text { sectional }\end{array}$ & $\begin{array}{l}\text { Wawancara dan } \\
\text { kuesioner }\end{array}$ & $\begin{array}{l}\text { Berdasarkan } \\
\text { kriteria inklusi }\end{array}$ & 15-20 tahun & Regresi \\
\hline
\end{tabular}


Tabel 4. Pengaruh Kenaikan Harga Rokok terhadap Perilaku Merokok

\begin{tabular}{|c|c|c|c|c|c|c|}
\hline Penulis & $\begin{array}{c}\text { Intervensi } \\
\text { terhadap Harga }\end{array}$ & Inisiasi Merokok & Pola Merokok & $\begin{array}{c}\text { Prevalensi } \\
\text { Merokok }\end{array}$ & $\begin{array}{c}\text { Koefisien } \\
\text { Elastisitas }\end{array}$ & Sensitivitas \\
\hline Asare et al. & Peningkatan $1 \%$ & $\begin{array}{l}\text { Mengurangi inisiasi } \\
\text { Ghana: } 3,66 \% \\
\text { Nigeria: } 1,04 \% \\
\text { Keduanya: } 2,8 \%\end{array}$ & $\begin{array}{l}\text { Mengurangi konsumsi } \\
\text { Ghana: } 1,13 \% \\
\text { Nigeria: } 0,44 \% \\
\text { Keduanya: } 0,9 \%\end{array}$ & - & $\begin{array}{l}\text { Inisiasi: }-2,8 \\
\text { Konsumsi: }-0,9\end{array}$ & - \\
\hline $\begin{array}{l}\text { Guindon et } \\
\text { al. }\end{array}$ & Peningkatan $10 \%$ & $\begin{array}{l}\text { Mengurangi } \\
\text { Laki-laki: } 5 \% \\
\text { Perempuan 3\% } \\
\end{array}$ & - & - & Inisiasi: $-0,4$ & $\begin{array}{l}\text { Laki-laki > } \\
\text { Perempuan }\end{array}$ \\
\hline Cui et al. & Peningkatan $10 \%$ & $\begin{array}{l}\text { Mengurangi } 15,7 \% \\
\text { pada siswa SMP } \\
\text { Keduanya: } 11,3 \% \\
\end{array}$ & $\begin{array}{l}\text { SMP: Mengurangi 19,3\% } \\
\text { SMA: Mengurangi 7,6\% } \\
\text { Keduanya: } 10,2 \%\end{array}$ & - & $\begin{array}{l}\text { Inisiasi: }-1,13 \\
\text { Konsumsi: - } \\
1,02 \\
\end{array}$ & $\begin{array}{l}\text { Siswa SMP > } \\
\text { Siswa SMA }\end{array}$ \\
\hline $\begin{array}{l}\text { Joseph \& } \\
\text { Chaloupka }\end{array}$ & Peningkatan 10\% & Mengurangi 4\% & - & - & Inisiasi: $-0,4$ & $\begin{array}{l}\text { Perempuan > } \\
\text { Laki-laki }\end{array}$ \\
\hline $\begin{array}{l}\text { Pförtner et } \\
\text { al. }\end{array}$ & Peningkatan harga & - & $\begin{array}{l}\text { Mengurangi } 0,78 \text { kali lebih besar pada } \\
\text { kelompok prasejahtera daripada } \\
\text { kelompok sejahtera }\end{array}$ & - & - & $\begin{array}{l}\text { Kelompok } \\
\text { prasejahtera } \\
>\text { sejahtera } \\
\end{array}$ \\
\hline $\begin{array}{l}\text { Nikaj \& } \\
\text { Chaloupka }\end{array}$ & Peningkatan $10 \%$ & - & $\begin{array}{l}\text { Mengurangi konsumsi rata-rata laki- } \\
\text { laki } 13 \% \text { dan perempuan } 8 \% \\
\text { Keduanya: } 0,9 \%\end{array}$ & $\begin{array}{l}\text { Mengurangi } \\
6,9 \% \text { pada } \\
\text { laki-laki }\end{array}$ & $\begin{array}{l}\text { Konsumsi: }-0,9 \\
\text { Prevalensi: - } \\
0,69\end{array}$ & $\begin{array}{l}\text { Laki-laki > } \\
\text { Perempuan }\end{array}$ \\
\hline $\begin{array}{l}\text { Sagitha et } \\
\text { al }\end{array}$ & $\begin{array}{l}\text { Peningkatan harga } \\
(2014-2018)\end{array}$ & - & - & $\begin{array}{l}\text { Tidak mampu } \\
\text { mengurangi }\end{array}$ & - & - \\
\hline
\end{tabular}




\subsubsection{Pengaruh Kenaikan Harga terhadap Pola Konsumsi Rokok}

Kenaikan harga juga memberikan pengaruh terhadap pola konsumsi rokok responden pada beberapa artikel yaitu pada penelitian Asare et al, Cui et al, Pförtner et al, dan Nikaj \& Chaloupka. Pada artikel Pförtner et al, hasil yang didapat dari penelitian sedikit berbeda yaitu hasil menunjukkan bahwa kelompok pra sejahtera mempunyai potensi penurunan konsumsi rokok mingguan saat harga naik 0,78 lebih besar daripada kelompok sejahtera. Sedangkan pada artikel Sagitha dkk, hasil penelitian menunjukkan bahwa kenaikan harga rokok yang telah diterapkan dalam rentang tahun 2014-2018 tidak mampu menurunkan konsumsi rokok.

Meskipun terdapat pengaruh kenaikan harga terhadap konsumsi rokok, namun pengaruhnya tidak begitu besar. Hal ini dikarenakan rata-rata koefisien elastisitasnya kurang dari 1, yang mana dapat diartikan perubahan harga kurang berarti terhadap perubahan permintaan terhadap rokok. Pernyataan ini sesuai dengan hasil penelitian Surjono \& Handayani (2018) yang mengutarakan bahwa permintaan rokok bersifat inelastis dengan hasil kenaikan harga pada tahun 2008 sampai 2010 hanya mampu menurunkan konsumsi rokok sebesar 0,4 sampai 0,7 .

Di lain sisi, terdapat beberapa penelitian yang mendukung pernyataan bahwa peningkatan harga tidak memberikan pengaruh terhadap konsumsi merokok. Sesuai dengan hasil penelitian Decicca dkk (2008) dalam Sugiharti et al (2015) dan Wandita (2020) yang menunjukkan bahwa tidak ada perubahan konsumsi secara bermakna akibat peningkatan harga rokok. Hal ini bisa disebabkan oleh perilaku merokok masyarakat yang beralih ke rokok yang lebih murah sebagai respon terhadap kebijakan peningkatan harga atau dikenal dengan istilah downgrade (Husain et al., 2017).

\subsubsection{Pengaruh Kenaikan Harga terhadap Prevalensi Merokok}

Harga rokok dan prevalensi merokok memiliki korelasi negatif berdasarkan hasil penelitian yang dipaparkan pada artikel Nikaj \& Chaloupka. Hal ini dapat diartikan bahwa harga rokok yang naik akan menurunkan prevalensi merokok. Pada artikel tersebut, disebutkan bahwa kenaikan harga 10\% dapat menurunkan prevalensi merokok pada kelompok remaja laki-laki sebanyak 6,9\%. Prevalensi merokok di Indonesia yang masih cenderung tinggi diakibatkan oleh harga rokok di Indonesia yang relatif murah. Hal ini sesuai dengan pernyataan Rasyid \& Hanny (2017) dalam penelitiannya bahwa apabila dibandingkan dengan Negara ASEAN, harga rokok di Indonesia relatif murah. Hal ini mendorong banyaknya perokok di Indonesia sehingga prevalensi merokok pun tinggi.

Hasil pada penelitian ini menunjukkan bahwa adanya peningkatan harga akan berdampak pada penurunan inisiasi merokok, konsumsi rokok, dan prevalensi merokok. Hal ini sesuai dengan hasil systematic review lain yang telah dilakukan oleh Brathwaite, Addo, Smeeth, \& Lock (2015) dan Wilson et al. (2012) yang menunjukkan bahwa dengan harga yang ditingkatkan akan mencegah perilaku merokok, mengurangi konsumsi rokok, bahkan menghentikan perilaku merokok. Pengaruh besar akan terjadi pada penurunan konsumsi rokok apabila harga ditingkatkan secara besar. Di Lain sisi, menilik artikel Cui et al. yang melakukan penelitian di salah satu negara maju yaitu Kanada menunjukkan hasil bahwa masih banyak remaja yang merokok meskipun undang-undang telah menetapkan usia legal untuk merokok adalah $\geq 18$ tahun dan melarang penjualan rokok pada anak atau remaja $\leq 18$ tahun (Ontario Tobacco Research Unit, 2013). Mayoritas remaja di Kanada mendapatkan rokok dari 
selundupan dan jejaring sosial (Harvey \& Chadi, 2016). Permasalahan rokok pada remaja nyatanya juga masih terjadi di negara maju yang sudah ketat dalam upaya pengendalian tembakau. Menilai banyaknya dampak yang diakibatkan oleh rokok yang salah satunya dapat menurunkan daya tahan kebugaran jasmani dan dapat berakibat buruk pada remaja sebagai generasi penerus bangsa (Kurniadi et al., 2019; Sari \& Nurrochmah, 2019). Apabila di negara berkembang seperti Indonesia tidak menerapkan kebijakan pengendalian tembakau yang maksimal salah satunya kebijakan peningkatan harga, maka permasalahan rokok pada remaja akan lebih sulit untuk diatasi.

\section{Simpulan}

Berdasarkan hasil analisis artikel-artikel yang telah dilakukan, maka dapat ditarik kesimpulan bahwa harga mempunyai korelasi negatif atau berbanding terbalik dengan perilaku merokok yang meliputi inisiasi merokok, konsumsi rokok, dan prevalensi merokok. Ini berarti apabila harga mengalami peningkatan maka akan menurunkan perilaku merokok. Pengaruh akan menjadi lebih besar apabila peningkatan harga yang diterapkan jauh lebih besar pula. Saran yang dapat diberikan kepada Pemangku kebijakan, akan lebih baik apabila Pemerintah memaksimalkan upaya pengendalian tembakau termasuk menerapkan peningkatan harga rokok secara besar agar pengaruh yang dihasilkan akan jauh lebih besar pada penurunan konsumsi rokok. Pasalnya, negara maju yang sudah memiliki aturan ketat dalam pengendalian tembakau masih mengalami permasalahan rokok pada remaja. Apabila Indonesia tidak memaksimalkan upaya dalam mengendalikan tembakau maka permasalahan akan lebih sulit diatasi. Selain itu, diberlakukannya simplifikasi untuk mencegah perokok beralih ke rokok yang lebih murah (downgrade) saat harga dinaikkan. Sedangkan saran untuk peneliti selanjutnya, akan lebih baik apabila penelitian dilakukan secara langsung untuk melihat sekaligus menilai kondisi riil di lapangan khususnya mengenai pengaruh kenaikan harga yang sudah diterapkan terhadap perilaku merokok di Indonesia dengan hasil penelitian ini sebagai bahan studi pendahuluan.

\section{Daftar Rujukan}

Afif, M. N., \& Sasana, H. (2019). Pengaruh kemiskinan, pendapatan per kapita, harga rokok, produksi rokok terhadap konsumsi rokok di Indonesia. Diponegoro Journal of Economics, 1(1).

Asare, S., Stoklosa, M., Drope, J., \& Larsen, A. (2019). Effects of prices on youth cigarette smoking and tobacco use initiation in Ghana and Nigeria. International Journal of Environmental Research and Public Health, 16(17), 1-14. https://doi.org/10.3390/ijerph16173114

Brathwaite, R., Addo, J., Smeeth, L., \& Lock, K. (2015). A systematic review of tobacco smoking prevalence and description of tobacco control strategies in sub-Saharan African countries; 2007 to 2014. PLoS ONE, 10(7), 1-17. https://doi.org/10.1371/journal.pone.0132401

Cahn, W. Z., Drope, J., Hamill, S., Islami, F., Liber, A., Nargis, N., \& Stoklosa, M. (2013). The tobacco atlas. In Choice Reviews Online (Vol. 50). https://doi.org/10.5860/choice.50-2422

Cooper, C. et al., (2018). Defining the Process to Literature Searching in Systematic Review of Guidance and Supporting Studies. BMC Medical Research Methodology.

Cui, Y., Forget, E. L., Zhu, Y., Torabi, M., \& Oguzoglu, U. (2019). The effects of cigarette price and the amount of pocket money on youth smoking initiation and intensity in Canada. Canadian Journal of Public Health, 110(1), 93-102. https://doi.org/10.17269/s41997-018-0123-9

Dartanto, T., Nasrudin, R., Hasibuan, J. \& Nuhasana, R., (2020). Tingkat Prevalensi Merokok pada Anak di Indonesia: Efek Harga dan Efek Teman Sebaya. [Online] Available at: https://sksg.ui.ac.id/policy-briefhasil-riset-pkjs-ui-tingkat-prevalensi-peningkatan-merokok-pada-kategori-anak-di-indonesia-efekharga-dan-efek-teman-sebaya/

Destri, Y., Sari, F. E., \& Perdana, A. A. (2019). Perilaku Merokok dan Faktor yang Berhubungan pada Siswa. Jurnal Kesehatan Metro Sai Wawai, 12(2), 18. 
Dua, P., \& Indonesia, N. (2018). Jurnal Bppk. 11, 35-48.

Fransiska, M., \& Firdaus, P. A. (2019). Faktor yang berhubungan dengan Perilaku Merokok pada Remaja Putra SMA X Kecamatan Payakumbuh. Jurnal Kesehatan, 10(1), 11. https://doi.org/10.35730/jk.v10i1.367

Gonzalez-Rozada, M., \& Montamat, G. (2019). How raising tobacco prices affects the decision to start and quit smoking: Evidence from argentina. International Journal of Environmental Research and Public Health, 16(19). https://doi.org/10.3390/ijerph16193622

Guindon, G. E., Paraje, G. R., \& Chaloupka, F. J. (2019). Association of Tobacco Control Policies with Youth Smoking Onset in Chile. JAMA Pediatrics, 173(8), 754-762. https://doi.org/10.1001/jamapediatrics.2019.1500

Handayani, P. W., (2017). Systematic Review dengan PRISMA (Preferred Reporting Items for Systematic Reviews and Meta-analyses). [Online] Available at: https://dosen.perbanas.id/wpcontent/uploads/2017/08/Sesi2-SYSTEMATIC-REVIEW-DENGAN-PRISMA.pdf

Harvey, J., \& Chadi, N. (2016). Preventing smoking in children and adolescents: Recommendations for practice and policy. Paediatrics \& Child Health, 21(4), 209-214. https://doi.org/10.1093/pch/21.4.209

Husain, M. J., Kostova, D., Mbulo, L., Benjakul, S., Kengganpanich, M., \& Andes, L. (2017). Changes in cigarette prices, affordability, and brand-tier consumption after a tobacco tax increase in Thailand: Evidence from the Global Adult Tobacco Surveys, 2009 and 2011. Preventive Medicine, 105, S4-S9. https://doi.org/10.1016/j.ypmed.2017.05.027

Joseph, R. A., \& Chaloupka, F. J. (2014). The influence of prices on youth tobacco use in India. Nicotine and Tobacco Research, 16(SUPPLEMENT1), 24-29. https://doi.org/10.1093/ntr/ntt041

Kementerian Kesehatan RI, (2018). Laporan Hasil Riset Kesehatan Dasar (Riskesdas) Indonesia Tahun 2018. Riset Kesehatan Dasar , pp. 182-183.

Kementerian Kesehatan RI, (2020). Rencana Strategis Kementerian Kesehatan Tahun 2020-2024. s.l.:s.n.

Kurniadi, D. A. E., Wahyudi, U., \& Heynoek, F. P. (2019). Hubungan Kebiasaan Merokok terhadap Tingkat Kesegaran Jasmani Peserta Ekstrakurikuler Futsal Putra. Sport Science and Health, 1(2), 126-131. http://journal2.um.ac.id/index.php/jfik/article/view/10631/4793

Mayhew, K. P., Flay, B. R., \& Mott, J. A. (2000). Stages in the development of adolescent smoking. Drug and Alcohol Dependence, 59(SUPPL. 1), 61-81. https://doi.org/10.1016/S0376-8716(99)00165-9

Nikaj, S., \& Chaloupka, F. J. (2014). The effect of prices on cigarette use among youths in the global youth tobacco Survey. Nicotine and Tobacco Research, 16(SUPPLEMENT1), 16-23. https://doi.org/10.1093/ntr/ntt019

Ontario Tobacco Research Unit. (2013). Youth Access to Tobacco Products : Monitoring Update. (September), 14.

Pförtner, T. K., Hublet, A., Schnohr, C. W., Rathmann, K., Moor, I., de Looze, M., ... Richter, M. (2016). Socioeconomic inequalities in the impact of tobacco control policies on adolescent smoking. A multilevel study in 29 European countries. Addictive Behaviors, 53, 58-66. https://doi.org/10.1016/j.addbeh.2015.09.016

Rachmat, M., Thaha, R. M., \& Syafar, M. (2013). Perilaku Merokok Remaja Sekolah Menengah Pertama. Kesmas: National Public Health Journal, 7(11), 502. https://doi.org/10.21109/kesmas.v7i11.363

Rasyid, \& Hanny, O. (2017). Dilema Produk Tembakau di Era Globalisasi: Studi Komparatif Rokok Indonesia dalam Lingkup ASEAN. Seminar Nasional Hasil Penelitian Sosial Ekonomi Pertanian Departemen Sosial Ekonomi Pertanian Fakultas Pertanian Universitas Gadjah Mada, 17-30.

Ratih, S. P., \& Susanna, D. (2018). Perceived effectiveness of pictorial health warnings on changes in smoking behaviour in Asia: a literature review. BMC public health, 18(1), 1-16.

Sagitha, C., Evi, S., \& Purwanti, Y. (2019). Pengaruh kenaikan harga rokok, pendapatan dan karakteristik perokok terhadap konsumsi rokok di kota semarang. Diponegoro Journal of Economics, 1, 22. Retrieved from https://ejournal2.undip.ac.id/index.php/dje

Sari, D. A., \& Nurrochmah, S. (2019). Survei Tingkat Kebugaran Jasmani di Sekolah Menengah Pertama. Sport Science and Health, 1(2), 132-138.

SEATCA. (2019). Tobacco Industry Interference Undermined Tobacco Tax Policy in Indonesia. Retrieved from https://seatca.org/dmdocuments/Indonesia TII in Tax.pdf 
SEATCA. (2021). SEATCA Tobacco Tax Index: Implementation of WHO Framework Convention on Tobacco Control Article 6 in ASEAN Countries Southeast Asia Tobacco Control Alliance. Retrieved from https://seatca.org/dmdocuments/SEATCA TOBACCO TAX INDEX ART6 2021 \%2820MAY21\%29 WEB.pdf

Sugiharti, L., Sukartini, N. M., \& Handriana, T. (2015). Konsumsi Rokok Berdasarkan Karakteristik Individu di Indonesia Cigarette Consumption Based on Individual Characteristic in Indonesia. Jurnal Ekonomi Kuantitatif Terapan, 34-45.

TCSC IAKMI. (2013). Remaja Dominasi Perokok Aktif di Indonesia. Retrieved from https://www.tcscindonesia.org/remaja-dominasi-perokok-aktif-di-indonesia/

Wandita, D. T. (2020). Pengaruh Cukai Rokok Terhadap Konsumsi Rokok Serta FaktorFaktor Yang Mempengaruhi Konsumsi Rokok. Jurnal Pendidikan Ekonomi, 14(1), 159-165. https://doi.org/10.19184/jpe.v14i1.16659

World Health Organization, (2003). WHO Framework Convention on Tobacco Control. [Online] Available at: http://www.who.int/tobacco/framework/WHO_FCTC_english.pdf

World Health Organization, (2016). Global NCD Target: Reducing Tobacco Use. [Online] Available at: https://www.who.int/beat-ncds/take-action/ncd-tobacco-target.pdf

World Health Organization, (2018). Factsheet 2018 Indonesia Heart Disease and Stroke are The CommonestWays by which Tobacco Kills People. [Online] Available at: http://www.searo.who.int/tobacco/data/ino_rtc_reports

Wilson, L. M., Avila Tang, E., Chander, G., Hutton, H. E., Odelola, O. A., Elf, J. L., ... Apelberg, B. J. (2012). Impact of tobacco control interventions on smoking initiation, cessation, and prevalence: A systematic review. Journal of Environmental and Public Health, 2012. https://doi.org/10.1155/2012/961724 